\title{
PÉREZ-REVERTE, Arturo. Los perros duros no bailan. Alfaguara, 2018, ISBN: 978-84-204-3269-4, 160 pp.
}

Más allá de la obvia conexión del título de la última novela de Arturo PérezReverte con la homónima en su traducción al español de Normal Mailer, Tough Guys Don't Dance (1984), Los perros duros no bailan apenas si juega con el hecho de que el protagonista, Nero, también conoce bien lo que es el mundo de las peleas clandestinas y sufre, como el protagonista de Mailer, de olvidos recurrentes y dificultad para pensar: "En ocasiones - y esto pasa con frecuencia- me quedo en blanco, o absorto con algo fijo clavado en la cabeza, y el cuerpo me hormiguea con un temblor extraño. Eso ya no es la edad, sino la memoria. No en vano durante dos años me estuve ganando la vida en lo que llaman peleas de perros, ya saben: un círculo —el Desolladero, en jerga perruna-" (12). Cierto es que ambas novelas nos adentran en un mundo sórdido, en el que se dan cita "un montón de humanos sudorosos y vociferantes apostando dinero, y dos púgiles de ojos enloquecidos enfrentándose [...]. A vida o muerte" (12-13). Pero mientras la novela de Mailer comienza con un borracho Tim Madden, ex camarero y extraficante de droga que apenas llega a fin de mes y que, sin saber cómo, tiene un tatuaje nuevo, una gran resaca, el asiento del pasajero de su coche lleno de sangre y se encuentra la cabeza decapitada de una mujer cerca de su casa; el protagonista canino de Pérez-Reverte comienza contándonos sus orígenes cual pícaro cervantino; unos orígenes que, al contrario de lo que ocurre con el personaje de Mailer, le han posibilitado un presente mejor. No en vano, la obra comienza con una referencia a El coloquio de los perros: "Desde que tuve fuerzas para roer un hueso, tuve deseo de hablar para decir cosas que depositaba en la memoria”. Desde la primera página, y gracias a la voz del propio Nero, sabemos que va a tratarse de un personaje típicamente perez-revertiano, con "ojos de viejo, alma llena de costurones y mirada resignada, hecha de girones de sangre y fatalidad. El hombre nos hizo asesinos, o casi, y lo sabemos. (11-12). Aquí no hay una mujer decapitada, pero nos enteramos por medio de Agilulfo, un can muy filosófico llamado como el primer rey lombardo que murió por causas naturales (590-616 A.D.), —algo impensable hasta la fecha-, de que algo va mal: "la desaparición de Teo y Boris el Guapo" (12).

Como buen personaje perez-revertiano, Negro es un héroe cansado que vive con los fantasmas de su pasado: "A menudo vuelvo en mí, desnudos los colmillos, gruñéndole al vacío tras creerme rodeado por gritos de humanos, humo de cigarrillos, espectros de perros a los que maté o dejé inválidos: los mismos que me infligieron en el cuerpo, y sospecho que también en algún lugar adentro, las marcas que entreveran mi pelaje oscuro." (13). Unos fantasmas que 


\section{RESEÑAS}

le hacen perder el control y "cuando se me va la olla me pongo a pelear contra el aire, como si estuviera majara" (13); igual que le ocurre a los boxeadores, sentencia Agilulfo (14). Esto le lleva a perder la noción del tiempo y a pasar "mucho tiempo dormitando bajo un puente del río, con un extraño rumor en los sesos" (16).

Negro reconoce que no hay peor lobo para uno que el de su misma especie, y pone en boca del cánido filósofo la máxima latina que tantas veces ha usado el escritor cartagenero: "Canis canis lupus -filosofó Agilulfo" (18). No obstante, al contrario que muchos de los héroes desanimados de Pérez-Reverte, como un Lucas Corso o un Faulques, Negro nos recuerda sobre todo a Alatriste; siempre dispuesto a pelear y, si es necesario, a morir por sus códigos y por los suyos: "Los perros de mi casta - todos los perros, a decir verdad- llevamos en los genes ciertas reglas y ciertos códigos" (24). Por encontrar a su amigo Teo, será capaz de pelear con quien sea e incluso de dejarse atrapar por la calaña más miserable de la sociedad humana. Su valentía, al igual que la del capitán, va acompañada de su reputación, la cual es especialmente necesaria para adentrarse en lo más siniestro de la sociedad: "Cada cual tiene su reputación, por maltrecha que ésta acabe yendo. En la mía no cabe cambiar de camino por un perro neonazi, ni siquiera por tres. A mí lo único que me hace quitarme de en medio son los empleados de la perrera municipal" (36).

Como novela negra, destapa las miserias de la sociedad y empieza por mostrarnos lo que hay detrás de los bajos fondos caninos para, después, pasar al horror provocado por los humanos. Ese recorrido comienza con un personaje con cierto aire a Makarova, tabernera y amiga de Corso cuyos "pantalones estrechos y camisa remangada hasta los hombros, y sus bíceps excesivamente fuertes no era lo único masculino que podía olfatearse en ella" (Pérez-Reverte, 1993: 6), si bien en Los perros se llama "Margot, la Porteña, la boyera de Flandes que se encarga del Abrevadero" (13). Para ella, el problema real de los perros viene por su contacto histórico con los humanos: "- -Todos somos chuchos, mirá. Desde que renegamos de la estirpe libre y orgullosa del lobo, el laburo de servir a los humanos nos envilese" (17).

Este bar perruno no sólo sirve de punto de encuentro para los protagonistas, como Mórtimer, que ayuda a Negro a recuperar a su amigo, o Fido, el perro policía "- un pastor alemán que curra en la comisaría del barrio-, [...]. No es mal animal, pero no es muy listo. Tampoco muy honrado. Solemos sobornarlo con facilidad: un hueso de jamón, unas chuches robadas a un niño. Vive y deja vivir" (29), como buen sabueso de novela negra. Aquí, las máximas de Agilulfo marcan el ritmo de los acontecimientos y de los sentimientos que los acompañan. Cuando la desaparición de Teo y de Boris el Guapo empieza a ser preocupante, 
el can filósofo se hace eco de Diógenes y habla de "irse a vivir a un barril" (22). Las penas se le quitan al ver aparecer a la irlandesa rubia, y "empezó a citar a un tal Dante y a una tal Beatriz" (27). Pero si recuerda la importancia de la amistad, opta por citar a Cicerón: “Amicitia lucet aequales" (30). Conforme las cosas se van poniendo más difíciles para recuperar con vida a los amigos, reflexiona sobre la relación entre la pena y el tiempo: "Afflictis lentae — dijo Agilulfo, solemne. En la tristeza, el tiempo va despacio" (56). Su influencia sobre Negro es tal que, aun no estando presente, éste le recuerda en un momento complicado "Como decía Agilulfo, un perro es esclavo de lo que ladra y dueño de lo que calla" (69), haciendo referencia a Sigmund Freud.

En su recorrido por los bajos fondos caninos, encontramos a Helmut, un dóberman frente a la librería de su dueño, Über Alles, (Alemania ante todo), "especializada, me parece, en cosas de la Segunda Guerra Mundial, o una guerra de ésas, con biografías de un tal Hitler — que por lo visto la lio buena hace tiempo- y personajes así. La clientela es gente más bien zumbada que va con botas de soldado, cazadoras bomber y la cabeza rapada, y de vez en cuando pasa por allí la policía y hay leña" (36). El mundo de los neonazis queda reflejado en "Helmut con sus ojos crueles y amarillos, [...] la esvástica que le colgaba del collar [...]. No es un cánido muy inteligente" (37) y sus compañeros Degrelle y Heinrich; siempre dispuestos a recordar con emoción a sus "abuelos en Auschwitz —apuntó, evocador. -O en Dachau" (38) y a despreciar a "esos inmigrantes [que] vienen y se instalan aquí como en su casa. Delincuentes, es lo que son. Escoria. Y nadie hace nada... Europa se va al carajo y nadie hace nada" (38).

De los neonazis nos lleva a su propio homenaje a Teresa Mendoza, su Reina del Sur. Aquí se llama Tequila, "una xoloitzcuintle mexicana, inmigrante, que se lo había montado bien, una cabrona con pintas. Peligrosa y sin escrúpulos. Su banda de perros callejeros controlaba todo el tráfico de huesos y restos de carnicería aprovechables al otro lado del río, cerca del puente nuevo" (34). Si bien ésta no había comenzado como "la morra de un narco bien puesta en casa, [...]. Una de tantas. Siempre lista para su hombre, que se lo devolvía de lujo. Bien padre. Con el Güero todo era reírse y coger" (Pérez-Reverte, 2002: 94), la Teresa Mendoza que tuvo que ir cambiando su vida hasta hacerse con el control del narcotráfico en un intento por sobrevivir. Tequila, desde que llegó de polizón en un barco portacontenedores, se mostró despiadada y lista, y en menos de un año se había hecho dueña de aquella parte de la ciudad. La jefa de jefes. Su nombre real era Lupe, pero la apodaban la reina Tequila; y hasta los Chuchos del Norte le habían compuesto aquel perro-corrido que decía: 
RESEÑAS

También las cánidas pueden

Ladrarte muy peligrosas.

Cuando se enojan son fieras

Esas caritas preciosas (42)

Su cuartel general, con "una pared cubierta de grafitis" (41), recuerda a las comunidades imaginadas de El francotirador paciente.

Pero, sin lugar a dudas, donde explora Pérez-Reverte el horror conradiano es cuando se adentra en el mundo de los hombres. Aquellos a los que, en la juventud canina, se les considera, sin excepción, "dioses buenos y leales" (49), y que, llegada su edad adulta, descubren que algunos de ellos "Venden droga y crían perros de pelea... Son gente peligrosa" (51). Negro se deja atrapar para adentrarse en este Corazón de las Tinieblas en dos fases. Primero, el Desolladero: "una nave industrial abandonada en las afueras de la ciudad, donde se celebraban las peleas de perros. Prohibidas por las leyes de los humanos, pero con la policía - ella sabría por qué- haciendo la vista gorda. Humo de cigarros, sudor, griterío cruel, billetes grasientos que cambiaban de dueño" (53). En este lugar, el protagonista se ve obligado a recurrir a sus viejos fantasmas y a enfrentarse a "profesionales de colmillos aguzados, músculos duros e instinto ciego de matar, ante los que te situabas vaciando la mente de todo cuanto no fuera pelear para sobrevivir" (53). Y la búsqueda de Teo y Boris le adentrarán aún más en este infierno humano para perros, la Cañada Negra:

Chabolas, coches grandes nuevos y viejos, abollados y polvorientos, objetos inservibles y amontonados: frigoríficos, televisores, lavadoras. Unos niños de aspecto sucio jugaban entre ellos, y un grupo de mujeres de faldas largas y pañuelos en la cabeza charlaban a lo lejos. A veces, ante la indiferencia de los críos y las mujeres, algún humano de mal aspecto, flaco y cochambroso, se acercaba por el camino que llevaba a la carretera de la ciudad, entraba en una chabola, salía al poco rato para sentarse cerca y se metía algo con una jeringuilla en un brazo o en los muslos, o los tobillos. Todo tenía aspecto sórdido y siniestro. (74)

Es aquí donde Los perros duros vuelve a aproximarse a la obra de Mailer, pero no a su ficción, sino a su ensayo "The White Negro". El escritor norteamericano habla de una época de conformismo y depresión que ha llenado de miedo cada poro de nuestro ser y ha dado lugar a una histeria y una parálisis colectiva en la que los actos de valor son esporádicos. Una época, como afirma Margot la Porteña, "de boludez y cambalache $[. .$.$] en que cualquiera se vende por un$ miserable hueso" (17). Y en medio de ella, el valor aislado de Negro, que se muestra como un perro valiente y leal "y en estos tiempos ya ni los perros lo somos" (61).

El mundo de las peleas obliga a los múltiples perros que allí se encuentran a 
aceptar convivir con la muerte en los términos que señala Mailer, "to live with death as immediate danger, to divorce oneself from society, to exist without roots" (1992: 339). Para aquellos que aceptan vivir rodeados por la muerte, "Death is their "logic"; living with it is their religion" (1992: 342). Y Negro acepta los términos impuestos por esta violencia humana con tal de salvar a su amigo. Por ese motivo, no duda en mostrar compasión con aquellos perros obligados a estar allí, pero que no quieren pelear: “-Será rápido—, dije. Lánzate contra mí y te aseguro que será rápido. Apenas sentirás nada — señalé a los humanos con el hocico. No les des la satisfacción de verte corretear como una liebre. [...] Acaba bien le dije. Como un verdadero perro" (86).

En palabras de Boris, aquel sitio es lo más parecido al Heart of Darkness de Joseph Conrad: “-El horror, dijo-. El horror" (100). Un sitio en el que "los humanos [...] toda aquella gentuza, toda aquella chusma canalla y despiadada, alzaba la vOz en un griterío ensordecedor, animándonos a despedazarnos. Exigiendo sangre y muerte" (126). Un lugar, como denuncia Mailer en "White Negro", en el que gran parte de la violencia se ejerce por parte del colectivo que está en control y frente a la cual sólo se puede erigir la violencia individual para conseguir la libertad y, quizás, soñar con una comunidad utópica. Negro se revela frente a la violencia de esta chusma humana, plenamente consciente de la lucha constante que ya de por sí implica vivir:

Siempre se trata del mismo combate, de la misma enloquecida y eterna desesperación. Dentelladas y sangre. La monotonía biológica de mantenernos vivos, de luchar para no perder la vida. La llamada de lo salvaje. Siglos de memoria y horror concentrados en un minuto de violencia cuerpo a cuerpo, guiado por el instinto combativo que, en el pasado, nos ha permitido a los canes y a los humanos sobrevivir allí donde otras especies, como solía decir Agilulfo, habían perdido el autobús de la supervivencia. (134)

En medio de esta violencia gratuita y sádica creada por los humanos, recordatorio de la mostrada por George Orwell en 1984,

Rara vez los cánidos rematamos a un enemigo que se proclama vencido. Aunque los perros somos lo que los amos hacen de nosotros, héroes o criminales, y no siempre un amo está a la altura de un perro, casi todos, excepto los que se vuelven locos, respetamos ciertas reglas caninas. $(127-128)$ 


\section{RESEÑAS}

Coincidir con Teo en el círculo del Desolladero supone el encuentro con alguien cuyos ojos se habían convertido "en dos círculos fríos de escarcha pálida, que miraban el mundo y me miraban a mí como si nada tuviera consistencia real" (137) por "las cosas vistas y los horrores vividos" (137). En torno a ellos, "estalló un vocerío humano ensordecedor, pero eso ya no tenía la menor importancia. Éramos Teo y yo, solos ante el mundo, envueltos en un abrazo mortal, peleando por nuestras vidas. Gladiadores sin futuro, sin patria y sin amo" (139).

Ante a violencia impuesta por el grupo humano, el estado en términos de Mailer, Teo y Negro se revelan, pues "allí en el Desolladero, no había amos, sino enemigos. A nadie nos ataba la lealtad. Todo era presa legítima y carne donde hincar el diente. Así que nos abalanzamos contra esa carne humana y esos ojos que de pronto nos miraban con espanto" (142). Su escapada triunfal, con reminiscencias de la Rebelión en la Granja orweliana, les hace sentirse "gloriosamente fatigados de morder y matar, de ajustar cuentas con aquel mundo bípedo y despiadado, tan ajeno a las duras pero justas leyes naturales (142-143).

En este momento de la narración entra el relato de Espartaco. Liberan a todos los perros allí enjaulados: "labradores, setters, bracos, canes de pedigrí selecto y también mestizos callejeros de varias clases y tamaños, machos y hembras. Perros robados a sus amos, unos, o capturados en el campo y las carreteras tras verse abandonados, otros" (149) y se congregan "sobre la loma, viendo elevarse el sol al otro lado de la ciudad" (150), al igual que hicieran Espartaco y los suyos alejándose de las siete colinas de Roma. De modo similar a lo que ocurrió con los ex-gladiadores que, separándose de Espartaco, siguieron a Crixo, un grupo de perros se fue por su cuenta, "un grupo salvaje que, poco a poco, engrosó con la llegada de otros proscritos abandonados o fugitivos. Y con el paso del tiempo, aquella jauría se había vuelto más dañina que una manada de lobos" (154). Su destino será similar al sufrido por Crixo y los suyos en el año 72 a.C. En los telediarios se ve a Teo enjaulado, mirando a

La cámara erguido y firme, desafiante, como diciendo: "Lo haría otra vez en cuanto me soltarais". Nunca lo había visto tan imperturbable, tan seguro de sí. Permanecía sentado sobre las patas traseras, musculoso y duro, con las fauces ensangrentadas y aquellos ojos que seguían pareciendo cuajados de escarcha, pero que ahora mostraban un brillo entre resignado y divertido. Un relampagueo irónico. [...] en la mirada del perro que había sido mi amigo [...] el balance de su existencia y nuestra amistad. (159)

Arturo Pérez-Reverte nos lleva por este recorrido intertextual de la mano de 
uno de sus personajes más similares al Capitán Alatriste, cuya frase inicial en la novela homónima "No era el hombre más honesto ni el más piadoso, pero era un hombre valiente", podría aplicarse perfectamente a Negro (con los cambios necesarios de "hombre" por "perro"). A modo de colofón, el famoso monólogo final de Blade Runner, "I've seen things you people wouldn't believe. Attack ships on fire off the shoulder of Orion. I watched C-beams glitter in the dark near the Tannhäuser Gate. All those moments will be lost in time, like tears in rain. Time to die" - "He visto naves ardiendo más allá de Orión"—, que ya usará en Territorio Comanche.

[José Belmonte SERrano/ Emilio RAmón García] 